\title{
Synergia konstrukcji i estetyki w małych mostach w Parczewie
}

\author{
Sławomir Karaś' ${ }^{1}$, Karolina Jankowska² \\ ${ }^{1}$ Katedra Dróg i Mostów, Wydziat Budownictwa i Architektury, Politechnika Lubelska, \\ e-mail: s.karas@pollub.pl \\ ${ }^{2}$ Budimex S.A., e-mail: karolina.jankowska@budimex.pl
}

\begin{abstract}
Streszczenie: Mosty ze względu na ich trwałość w krajobrazie stają się punktami odniesienia w różnych aspektach, w tym w szczególności społecznym, architektonicznym i estetycznym. Można mnożyć przykłady opisanych sytuacji, są to np. Tower Bridge, Puente del Alamillo, Pont Saint-Bénézet (d'Avignon), Karlův most czy Ponte Sant'Angelo. Jednakże celem analiz w niniejszym artykule są mosty zajmujące skrajnie marginalną pozycję do wymienionych sławnych mostów. Są to małe mosty przez rzeki Konotopa i Piwonia w miejscowości Parczew na Lubelszczyźnie. Lokalna społeczność dostrzegła konieczność zmiany z szarej monotonii na formy bardziej atrakcyjne o indywidualnych cechach. Jeśli istniejące mosty będą zadbane, zaaranżowane, przez podkreślenie istotnych linii silną lub delikatną barwą, nawiązanie do otoczenia przez zharmonizowanie lub przez utworzenie lokalnej dominanty. Wiele już zrobiono, kilka zaniedbanych obiektów oczyszczono, odnowiono, zmodernizowano balustrady i pomosty, uporządkowano stożki skarp, zadbano o wyraźną kolorystykę elementów. W referacie przedstawiono wszystkie mosty w mieście, ale także w okolicach Parczewa, z tego względu, że te obiekty funkcjonują w świadomości mieszkańców. Dotyczy to tak mostów drogowych jak i kolejowych. Podano zamieszczono skrótowo ich charakterystyki użytkowe, historię i subiektywne oceny estetyczne. Aplikacją ujętej powyżej koncepcji jest projekt niewielkiej kładki dla pieszych w trzech wariantach, przy czym poza względami wytrzymałościowo-funkcjonalnymi podstawowym zadaniem projektanta było stosowanie rozwiązań prostych i wizualnie interesujących, cokolwiek by to nie znaczyło.
\end{abstract}

Słowa kluczowe: mosty, małe miasta, estetyka, zrównoważony rozwój.

\section{Mosty - punkty węzlowe}

Znaczenie mostów podkreśla przyjmowanie nazw od tych obiektów. Przykładami mogą być miejscowości Mostar, Puente la Reina, Wysokie Mosty oraz lokalne przysłowia np. Viele Brücken führen nach Bern ${ }^{1}$. Na moście Karola w Pradze miała ostatnia bitwa wojny trzydziestoletniej, 1648 r., w czasie II wojny światowej walki o mosty w Holandii i Niemczech (Market Garden) zrodziły powiedzenie o jeden most za daleko [1].

Mosty królewieckie są najsławniejszym zespołem mostów. Od tych mostów rozpoczęła się w sensie naukowym topologia, a dokładniej teoria grafów. 7 starych mostów nad Pregołą to punkty węzłowe, drogi dojść do mostów to krawędzie. Można rozważyć 2 problemy: po pierwsze - przez każdy z mostów można przejść tylko jeden raz, po drugie - po każdej krawędzi można przejść tylko jeden raz. Drugi z wariantów to pierwsze rozwiązane zagadnienie w historii teorii grafów. Rozwiązanie zostało zamieszczone w artykule, który zainicjował

Wiele mostów prowadzi do Berna 
badanie grafów, była to praca Leonharda Eulera Solutio problematis ad geometriam situs pertinentis ${ }^{2}$ znana powszechnie pod nazwą Zagadnienie mostów królewieckich. W topologii problem ten nosi nazwę grafu eulerowskiego i jest znacznie ogólniejszy niż wzmiankowane zadanie historyczne. Na Rys. 1. zamieszczono współczesno mapę (Google) z zaznaczonymi mostami oraz stare zdjęcie w ujęciu z lotu ptaka z widokiem na 4 mosty.
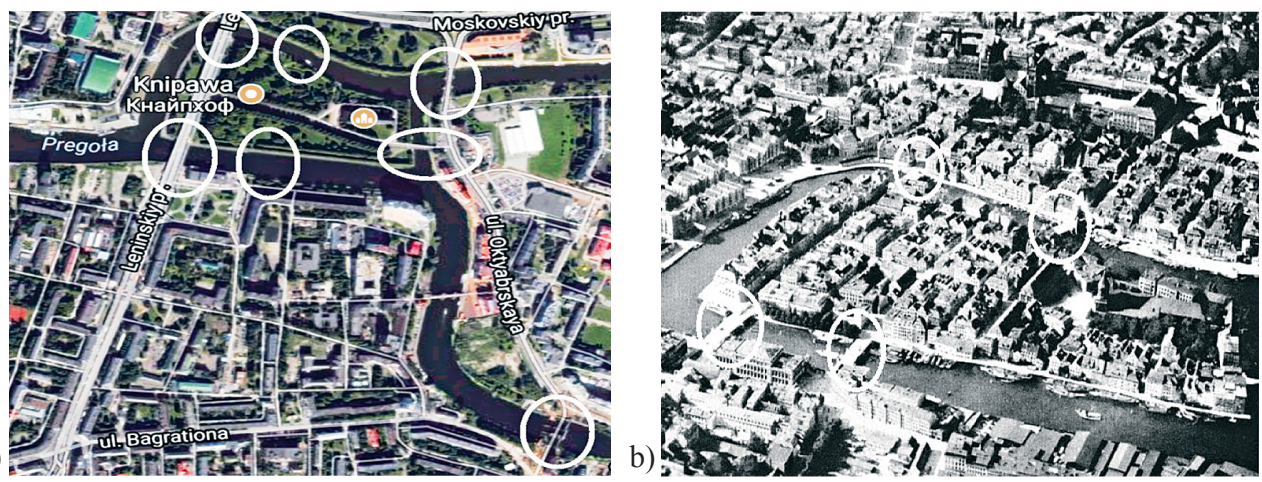

Rys. 1. Topologia - zagadnienie mostów królewieckich a) historyczne usytuowanie mostów królewieckich na współczesnej mapie Kaliningradu (Google) b) fotografia ${ }^{3}$ obejmująca swym zakresem 4 mosty królewieckie (cztery z siedmiu)

Jak widać na Rys. 1.a, dwa z opisywanych mostów, już nie istnieją, jednakże zrodzona tu myśl utrwaliła je na zawsze.

\section{Istniejące mosty i kładki w Parczewie oraz w okolicach}

A)

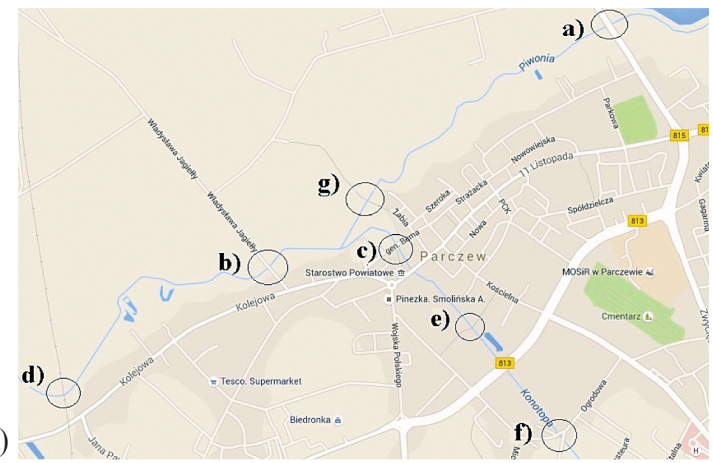

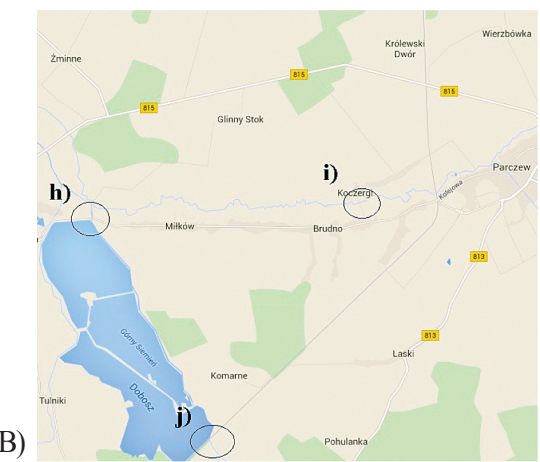

Rys. 2. A) Parczew: a) most drogowy na ul. Lubartowskiej, b) most drogowy na ul. Wł. Jagiełły, c) nowy most drogowy na ul. Bema, d) most kolejowy nad rzeką Piwonia, e) kładka dla pieszych nad rzeką Konotopa, f) most drogowy na ul. Ogrodowej, g) kładka nad rzeką Piwonia B) okolice Parczewa: h) Siemień - most drogowy z zaporą wodną nad rz. Tyśmienica, i) Koczergi: kładka dla pieszych nad rz. Piwonia, j) Laski - most kolejowy nad rz. Tyśmienicą

\footnotetext{
2 Solutio problematis ad geometriam situs pertinentis, (Rozwiązanie zagadnienia powiązanego z geometrią położenia), Commentarii Academiae scientiarum imperialis Petropolitanae (CASP - Volume 8: 1736, 1741, 128-140). Przedtawiono podczas wykładu w Petersburskiej Akademii Nauk 9. czerwca 1735 r. http://eulerarchive.maa.org/pages/E052.html [12.07.2017]

http://www.ostpreussen.net/backup2009/daten/ostpreussen/module/data/bilder/38/38010302g.jpg
} 
Miasto Parczew, mimo niedużej wielkości, jest miejscem bardzo bogatym kulturowo, z długą i ciekawą historią oraz z wieloma zabytkami i atrakcjami. Przepływają tędy dwie rzeki. Piwonia wyznacza północną granicę miasta, zaś rzeka Konotopa jest jej głównym lewym dopływem i dzieli miasto na dwie części. Mosty i kładki dla pieszych znajdują się nad obiema rzekami. Większość z mostów wskazanych na Rys. 2., jest przedmiotem analizy zamieszczonej poniżej.

Przed pierwszą wojną światową istniały w Parczewie 4 mosty - dwa na rzece Piwonii, na trakcie radzyńskim (ok. 4 metry szerokości), jeden na drodze Parczew-Brześć (ok. 2 metrów) oraz na Konotopie (ok. 1,5 metra szerokości). Pobierano przy nich tzw. opłaty kopytkowe. Wartość każdego mostu szacowana była na ok. 1400 rb. Po wybudowaniu drogi z Lubartowa do Parczewa i przy tym kolejnego mostu na rzece Piwonia, stary most na Piwonii (dzisiejsza ul. Wł. Jagiełły) stracił znaczenie gdyż omijał miasto [2].

Most na ulicy Lubartowskiej jest mostem belkowym jednoprzęsłowym o konstrukcji żelbetowej. Jego rozpiętość teoretyczna to $14 \mathrm{~m}$, a szerokość ok. 6,5 m. Stanowi główny wyjazd z miasta, więc przenosi duże natężenia od ruchu pojazdów.

Stary most na ulicy Władysława Jagiełły był konstrukcją drewnianą, łukową. Do dziś zaobserwować można pozostałości po drewnianych palach, na których wspierał się most. Po przebudowie mostu w latach 70-tych konstrukcja zmieniona została na jednoprzęsłową, żelbetową, o płycie nośnej wspartej na belkach kablobetonowych typu WBS (Rys. 3). Jego długość to $15 \mathrm{~m}$, a szerokość ok. 5,5 m. Belki wsparte są na łożyskach, a te na ciosach podłożyskowych. W środku konstrukcji zastosowano belkę poprzeczną niepełną, a w miejscach podparć płyty głównej belki poprzeczne pełne.
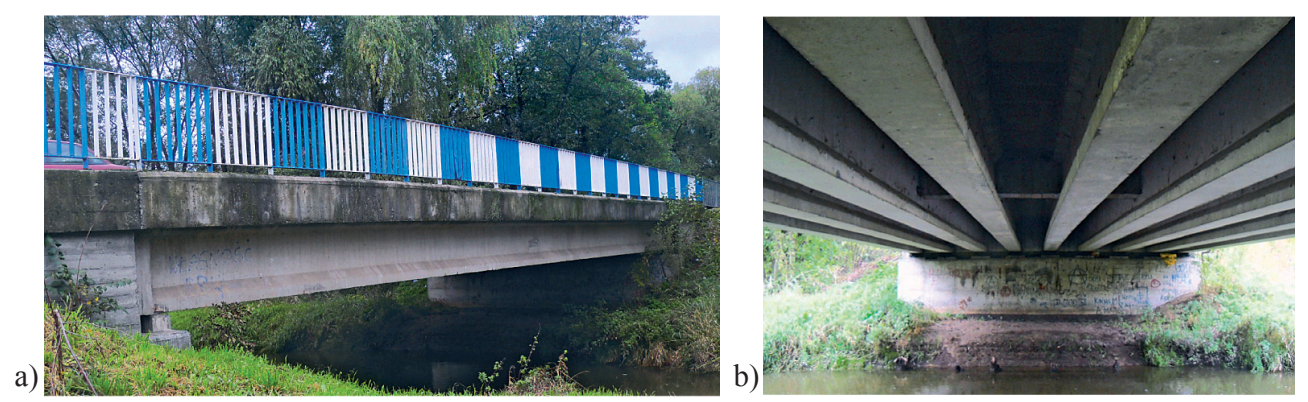

Rys. 3. Most na ul. Wł. Jagiełly a) widok z boku b) widok od spodu na belki i poprzecznice

Obiekt mostowy przez rzekę Konotopę w ciągu drogi powiatowej Nr 1629L, ul. Bema, przeszedł kapitalny remont w 2014 r. Obiekt odnowiono i wzmocniono. Zmieniono otoczenie obiektu tj. schody i dojazdy.

Przęsła barier to wyraźna krata, na której umieszczono półprzezroczyste, niebieskawe przepony ze szkła hartowanego. W widoku z boku odpowiednio zastosowano symulację łuku do "masywnych" filarów przechodzących w równie masywne fragmenty balustrad. Na barierach umieszczono dwa herby, z jednej strony herb powiatu parczewskiego, z drugiej zaś herb Parczewa. Rzeczywista szara konstrukcja płytowa podkreśla krzywiznę łuku. Te niewielkie ingerencje architektoniczne zmieniły całkowicie estetykę mostu przez jego zindywidualizowanie i wytworzyły barwną dominantę krajobrazu. Po mistrzowsku elewację mostu zaprojektował arch. Leszek F. Szkutnik. 
a)

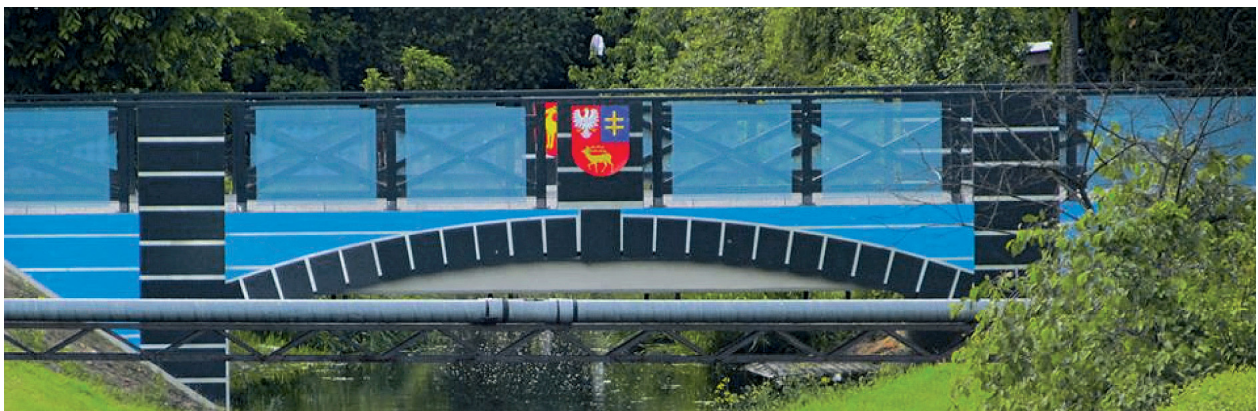

b)

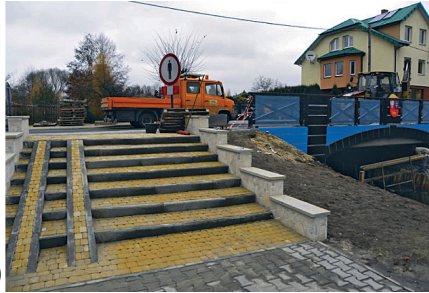

c)
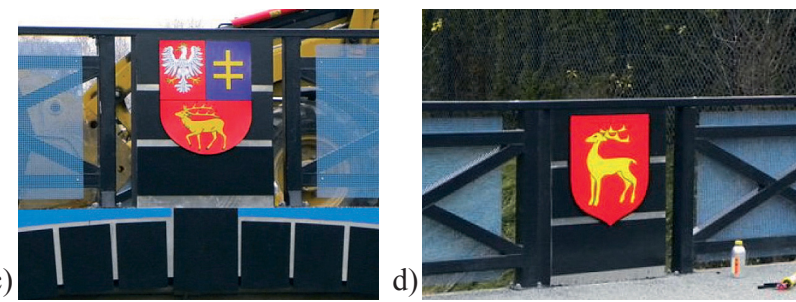

Rys. 4. Most na ul. Bema a) widok z boku b) schody c-d) herby powiatu parczewskiego i miasta Parczew

Estetycznym odniesieniem do mostu z Rys. 4 jest most pokazany wcześniej na Rys. 3 . Należy uznać, że most na ul. Wł. Jagiełły jest bardzo starannie utrzymanym obiektem. Jego stan techniczny jest również nienaganny, ale dopiero w zestawieniu dwóch obrazów tych dwóch obiektów widać jak można zwykły most adaptować by stan synergii, a może nawet dumy.

Most stanowi przeprawę przez rzekę Konotopa w samym centrum miasta - jest głównym dojazdem do Urzędu Miasta oraz Parczewskiego Domu Kultury. Swoją nową estetyką i kolorystyką wzbudza podziw i stanowi wizytówkę miasta. Pełni funkcję nie tylko komunikacyjną, ale także promocyjną i wizerunkową, a sądząc po lokalizacji - także polityczną. W kategoriach powszechnych mamy do czynienia z interesującym landmark, który nawiązuje do heraldyki miasta, wprowadza istotne odróżnienie do otoczenia i innych obiektów mostowych. Wartość inwestycji to ponad 515 tysięcy zł.

W 1898 roku powstała linia kolejowa łącząca Lublin z Parczewem oraz biegnąca dalej do Łukowa. Kursowały tędy pociągi relacji Lublin-Siedlce, Lublin-Gdynia i Lublin-Białystok. Niestety w 2000 roku linie zamknięto ze względu na mały popyt na tą formę komunikacji oraz zły stan torów. Ruch przywrócono na trasie Lublin-Parczew dopiero w 2013 roku. Trwają pracę nad dalszym odcinkiem torów, aby przywrócić całkowicie ruch pociągów z lat ubiegłych. Odnowienie linii kolejowej przyczyniło się do powstania ciekawych obiektów mostowych zarówno w mieście Parczew, jak i okolicach.

Most kolejowy na rzece Tyśmienica (okolice Lasek), Rys. 5, ma 45 metrów długości, 9 metrów wysokości i waży 1,2 MN. „Nowy” most to w istocie konstrukcja zdemontowana i ponownie złożona w całość. Zdemontowano go i sprowadzono z modernizowanej linii kolejowej Warszawa-Moskwa. Rozebrany kolos dotarł w częściach do stacji kolejowej Parczew, gdzie po generalnym remoncie znów został złożony w całość. Most jest konstrukcją kratownicową o schemacie Warren'a ${ }^{4}$ ze słupkami i wieszakami. Węzły łączone na nity zostały dodatkowo wzmocnione blachą z obydwu stron. Autorem całości przedsięwzięcia jest Zygmunt Grzechulski.

\footnotetext{
4 Patent Jamesa Warren'a z 1846 roku.
} 
b)

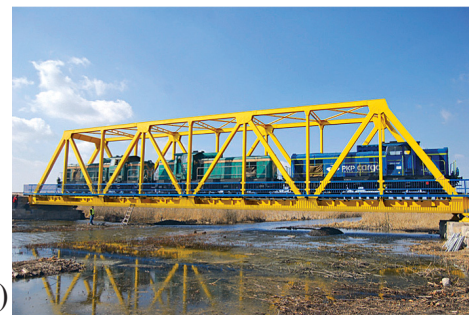

c)

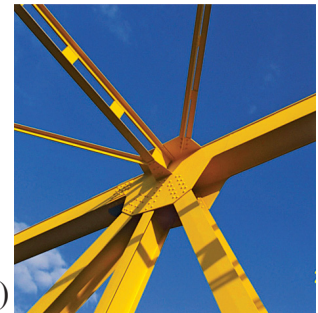

d)

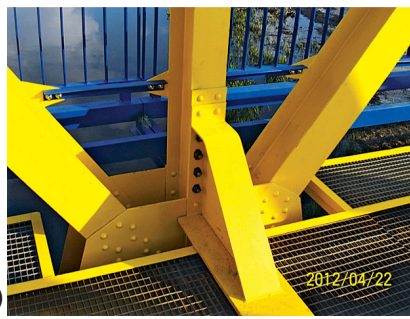

Rys. 5. Most kolejowy przez rz. Tyśmienicę a) widok z boku - próbne obciążenie b-c) szczegóły węzłów

Mechaniczną ideą kratownicy jest przeniesienie zginania przez równoległe pręty, pas dolny i górny, przez jednoczesne wywołanie w nich dominujących stanów odpowiednio rozciągania i ściskania oraz takie ich rozstawienie wysokościowe by relatywnie niewielkie siły osiowe działały na dużym ramieniu. Pręty ukośne - krzyżulce, przenoszą siły poprzeczne. Zastosowane słupki i wieszaki zmniejszają lokalne zginanie pasa dolnego, podczas gdy w pasie górnym redukują długości wyboczeniowe. Nie ma w kratownicy żadnego nadmiaru lub przypadkowości. To jest czysta mechanika budowli. Jak widać z tej charakterystyki, kratownica jest inteligentną, mechanicznie synergiczną strukturą.

Kratownica zawsze wywołuje efekt przestrzenny i lekkości. Relatywnie wiotkie pręty łączone w węzłach tylko podkreślają jej niebywałą ażurowość, a w zestawieniu z masywnością pociągu, mogą powodować dreszcz lęku o jej nośność.

W latach minionych kratownice pokrywano farbami o barwie szarej lub zielonej, co dawało efekt redukcji ich wymiarów i ukrywało przemysłowość stalowej konstrukcji podczas dni pochmurnych. Obecnie bardzo często kratownice są malowane na żółto z niebieskimi balustradami, które lekko żółć podkreślają, co udało się uchwycić na zdjęciach na Rys. 5. Zdaniem autorów żółte kratownice są stwarzają wrażenie ciepła niezależnie od pogody.

a)

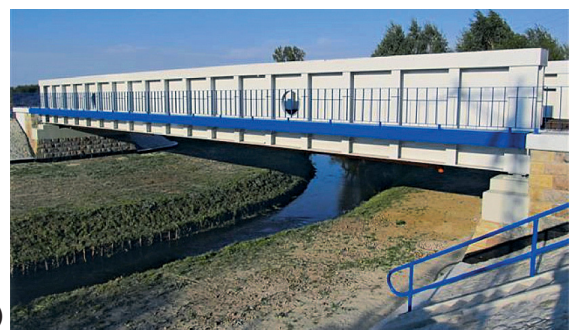

b)

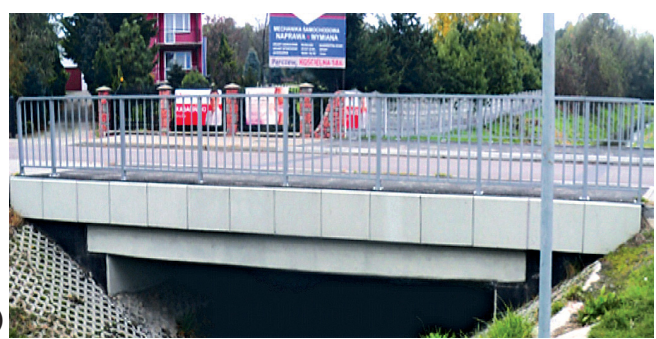

Rys. 6. Dwie różne konstrukcje mostowe a) most kolejowy na rz. Piwonia b) ul. Ogrodowa, most na rz. Konotopa

Na Rys. 5 ukazano dwie rózne, w sensie obrazu estetycznego, konstrukcje. Rys. 6.a to most o schemacie ramownicy Vierendeela, nazywanej tradycynie kratownicą Vierendeela, [3]. To trudna mechanicznie struktura. W skrócie mozna powiedzieć, że jest to kratownica bez krzyżulców. Efektem jest występowanie masywywnych słupków, pasów i znacznie rozbudowanych wężłów. Niemal wszystkie mosty o tym schemacie są „za ciężkie”. Pomimo to w odtatniej dekadzie obserwuje się w świecie duże zainteresowanie tą konstrukcją. Przykładami może być stalowa kładka Heinemanna w centrum Berlina czy betonowy wiadukt Puente de Osera de Ebro. Na pewno prostolinijność i czytelność konstrukcji, dbałość o detale, [4], jako elementy niezbedne w estetyce mostu są tu natychmiast dostrzegalne. 
Szara ściana dźwigara jest skontrastowana równym rytmem słupów łączących pas dolny z górnym, wszystko jest podkreślone/odkreślone silną wstęgą pomostu roboczego z ustawioną na nim delikatną firanką szczeblinek. W stalowej ścianie - środniku między słupami - umieszczo symetrycznie dwa otwory koliste, które rozbijają monotonię i skupiają na sobie uwagę. Przyczółki mostu są niewysokie, łączą w sobie starą konstrukcję z ciosanego naturalnego kamienia zwieńczona nadbudowaną niską betonową ławą podłożyskowa z ciosami, na których ustawiono przęsło. Zdjęcie wykonano zaraz po przebudowie, dlatego regularnie ukształtowane koryto rzeki, tu w łuku, nie jest jeszcze zielone od zasianych traw łąkowych. Bez wątpienia most można określic jako elegancką konstrukcję.

Most drogowy na ul. Ogrodowej, na rzece Konotopa (Rys. 6.b), jest obiektem przeciętnym sam w sobie i w jego otoczeniu, płyta o długości 7,4 m, szerokość 13,5 m. Most jest usytuowany w ukosie i w łuku poziomym. W roku 2010 miał miejsce remont, który obejmował wymianę nawierzchni jezdni i chodników, krawężników, balustrad, montaż desek gzymsowych z polimerobetonu oraz umocnienie skarp. Most pod względem technicznym jest bez zarzutu. Przyjmując kryteria poprawności architektonicznej wg Wasiutyńskiego [5], obiekt spełnia je wszystkie, jednakże jest to estetyka bez emocjonalnej impresji.

Podobną zasadę zestawienia dwóch mostów zastosowano na Rys. 7. Zdjęcia dwóch kładek dla pieszych, przy czym każda z nich jest skrajnie prostą konstrukcją, także kładkę w Korczegach należy klasyfikować, jako wernakularną, Rys. 7.b. Obie kładki dla pieszych mają minimalną szerokość skrajni dla dwóch pojedynczych pieszych, tj. 1,5 m.

Każdy most jest ważny [1]. Z tego powodu, zawsze budowano i dalej będą budowane konstrukcje tymczasowe często o niskich charakterystykach estetycznych, ale za to, spełniających ważne funkcje transportowe oraz oczywiście warunki techniczne użytkowania.

a)

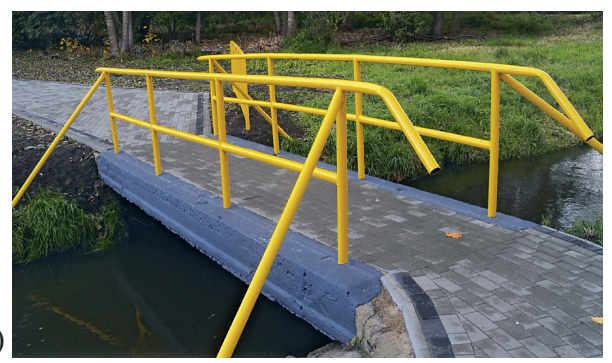

b)

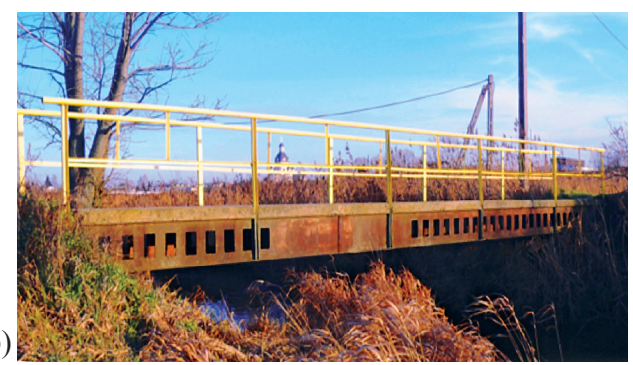

Rys. 7. a) Kładki dla pieszych a) nad rz. Konotopa, Parczew b) nad rz. Piwonia w m. Korczegi

Kładka dla pieszych nad Konotopą, Rys. 7.a, służy głównie młodzieży śpieszącej do zlokalizowanych nieopodal szkół średnich. Została odrestaurowana w 2014 roku. Nowa żelbetowa płyta jest oparta na istniejących przyczółkach. Nawierzchnia z kostki brukowej została ułożona ciągiem wraz z wejściem i zejściem z kładki i połączona z istniejącym chodnikiem. Stalowe balustrady nie tylko zostały przymocowane do kładki, ale także wsparte dodatkowo o skarpy po jednej i drugiej stronie rzeki. Prosta i ładna konstrukcja, z wyraźnie wydzielonym ciągiem pieszym oraz zwyczajną balustradą z przeciągami z rur stalowych. Mały detal techniczny - zastrzały stabilizujące balustradę - czynią całą kładkę konstrukcją przestrzenną. Wyraźna i przyjazna kolorystyka wyróżniają kładeczkę spośród innych.

Kładka dla pieszych Koczergach, Rys. 7.b, jest przykładem konstrukcji tymczasowej, która oparła się zmianom niesionym przez czas. Konstrukcyjnie kładka nie budzi zastrzeżeń. Dodatkowo jej konstrukcja jest o tyle ciekawa, że betonowa płyta wsparta jest na stalowych 
kształtownikach - dwuteownikach ażurowych, typu Bażykówka ${ }^{5}$. Belki dwuteowe posiadają prostokątne otwory, które mają na celu podwyższenie środnika, przez co konstrukcja posiada większą sztywność i nośność. Dziś ta kładka wygląda na przypadkowo zastosowany złom do budowy mostu, jednakże estetycznie daje duże możliwości i w tym kontekście czeka na rękę architekta na miarę efektu pokazanego na Rys. 4.a.

Na Rys. 8. przedstawiono most, który w kategoriach estetycznych jest trudny. Pełni dwie funkcje, jest mostem a jednocześnie pracuje pod nim urządzenie mechaniczne piętrzące wodę. W tej sytuacji pole manewru jest bardzo ograniczone i pokazana zwykła dbałość, standardowe utrzymanie wyczerpuje to, co można tu zdziałać.

a)
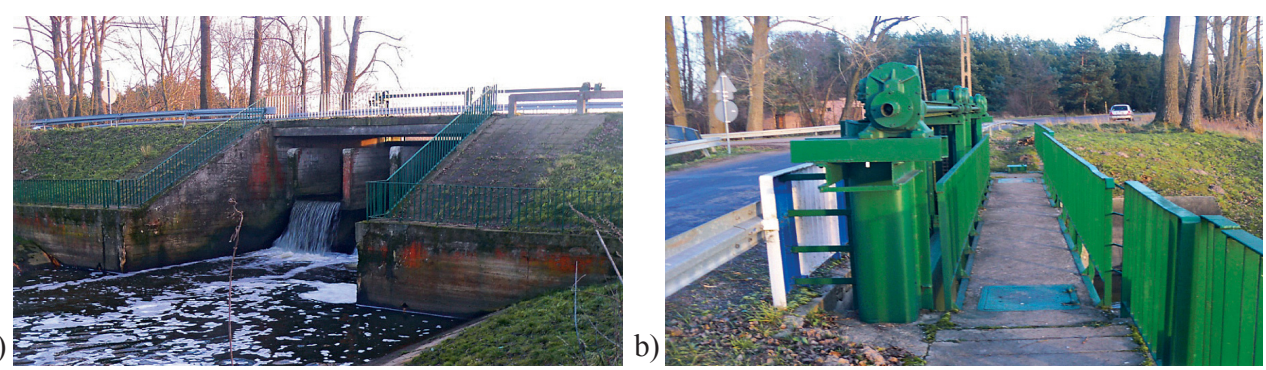

Rys. 8. a) Siemień, most z zastawką wodną nad rzeką Tyśmienica, b) chodnik dla pieszych

Jednakże, niezaprzeczalnie ten most ma w sobie szczególny walor, którym jest towarzyszący jego obrazowi szum wody. Spośród licznych szumów traktowanych, jako hałas, ten jest przyjazny do tego stopnia, że wywołuje relaks i ukojenie.

Reasumując rozdział, konstrukcje mostowe w mieście Parczew spełniają głównie funkcję komunikacyjną miasta i rzadko stanowią wzbogacenie estetyczne i architektoniczne. Generalnie nie promują miasta i nie mogą w żaden sposób stanowić atrakcji turystycznej miasta. W ostatnich latach widać pewną zmianę w myśleniu projektowym i w przypadku remontów mostów zaczęto zwracać większą uwagę na walory estetyczne, kolorystykę i aspekt architektoniczny, lecz jest to jeszcze zabieg świeży i wykorzystywany w małym stopniu. Dlatego też projekt nowej kładki dla pieszych, która mogłaby wzbogacić miasto pod względem turystyki i estetyki wydaje się być wymogiem chwili.

\section{Projekt niewielkiej kladki dla pieszych w trzech wariantach}

Według planu strategicznego na najbliższe lata, w ramach zwiększenia atrakcyjności miasta Parczew, ma powstać park miejski. Planowana kładka ma być usytuowana w parku nad rzeką Konotopa, Rys. 9.

Szerokość koryta rzeki mierzona na poziomie lustra wody wynosi $6 \mathrm{~m}$, podczas gdy zakresie korony koryta jest to $\sim 10 \mathrm{~m}$. Założono, że oś kładki będzie lokalnie prostopadła do osi cieku. Nie przewiduje się budowania schodów i ramp, lecz zakłada się ciągłość konstrukcji z otaczającą przyszłą architekturą krajobrazu. Jego główną rolą ma być funkcja komunikacyjna, umożliwiająca połączenie dwóch części parku, a poboczną - funkcja promocyjna miasta. Na kolejnych rysunkach, Rys. 10-12, przedstawiono 3 projekty/warianty kładki, przy

\footnotetext{
5 Barzykowski Wojciech (1900-1983), mgr inż., budowniczy mostów Twórca Barzykówek - stalowych belek rozpowszechnionych w polskim mostownictwie w latach 60 . i 70.
} 
a)
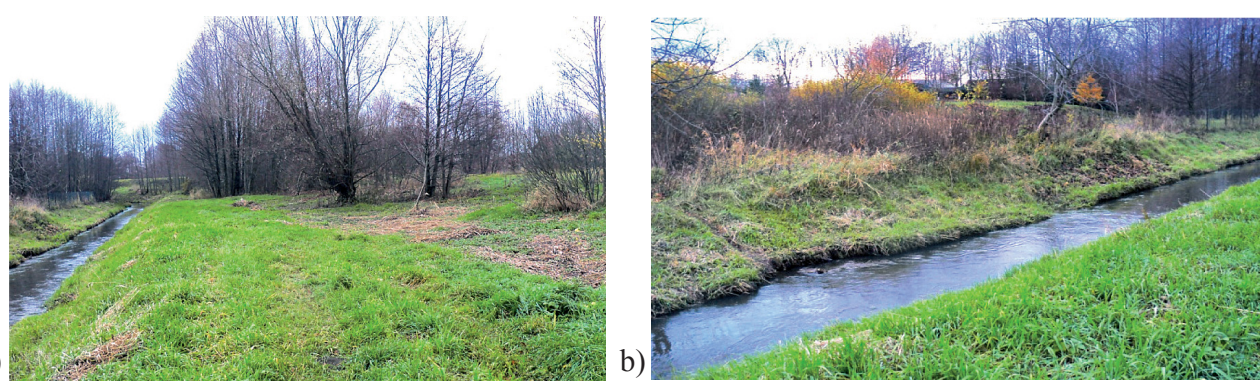

Rys. 9. Teren inwestycyjny a-b) planowany park miejski, rz. Konotopa

czym są to szkice ukazujące przekrój podłużny obiektu i przekrój poprzeczny z podstawowymi wymiarami. W zakresie ściśle technicznym, wszystkie 3 warianty są nazbyt wymyślne i zdecydowanie droższe niż typowa kładka swobodnie podparta o długości $12 \mathrm{~m}$, ale takie są dodatkowe koszty gdy dążymy do uzyskania interesującego indywidualnego efektu. Z założenia nie uwzględniono kolorystyki mostów, gdyż etap koncepcyjny jest jedynie po to by sprawdzić stany graniczne nośności i użytkowalności, co też miało miejsce. Wymiary na rysunkach są $\mathrm{w}[\mathrm{cm}]$.
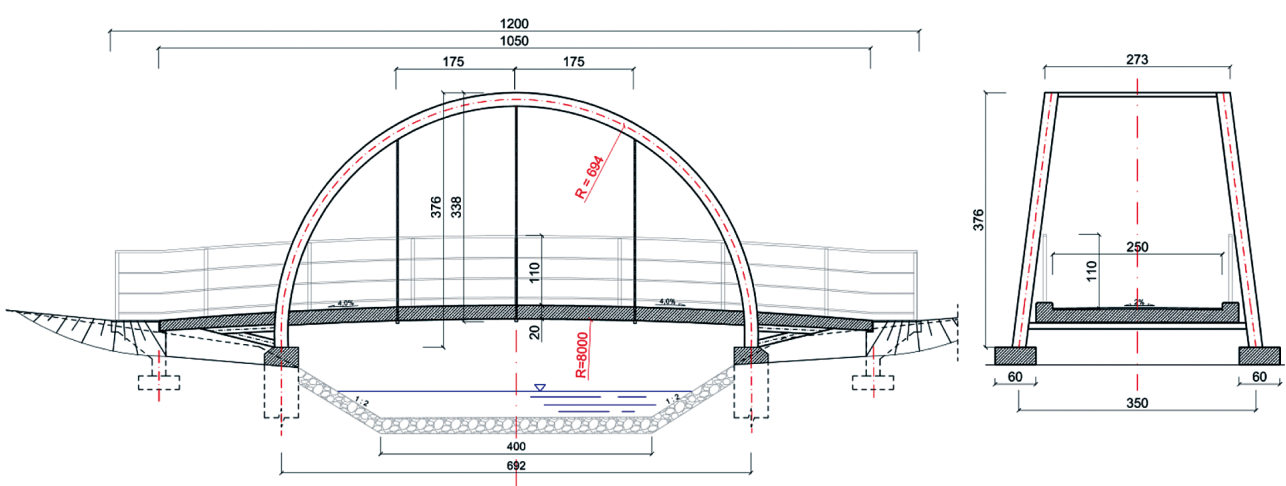

Rys. 10. Kładka łukowa - wariant 1

Mosty łukowe mają wpisane, przez swój naturalny kształt, łatwo przyswajalne piękno [6]. To się zdarza, chociaż bardzo rzadko, że most łukowy jest konstrukcją niezgrabną, turpistyczną i ogólnie nieciekawą. Mając to na uwadze zdecydowano o wyborze kształtu dźwigara nośnego jako łuku półkolistego o promieniu $R=6,94 \mathrm{~m}$, Rys. 10. Dodatkowo pomost jest wyniesiony łukiem kolistym o promieniu $R=80 \mathrm{~m}$. Krzywa pomostu jest potęgowana liniami prostej (nieskomplikowanej) balustrady z przeciągami łukowymi równoległymi do pomostu. Zastosowano różne materiały: łuk i balustrada są metalowe, a płyta pomostu żelbetowa $\mathrm{z}$ betonu samozagęszczalnego o niewielkiej grubości równej $20 \mathrm{~cm}$. Pomost jest podwieszony do każdego z łuków trzema wieszakami cięgnowymi stalowymi. W przekroju poprzecznym łuki są pochylone do wewnątrz pod kątem $7^{\circ}$. 


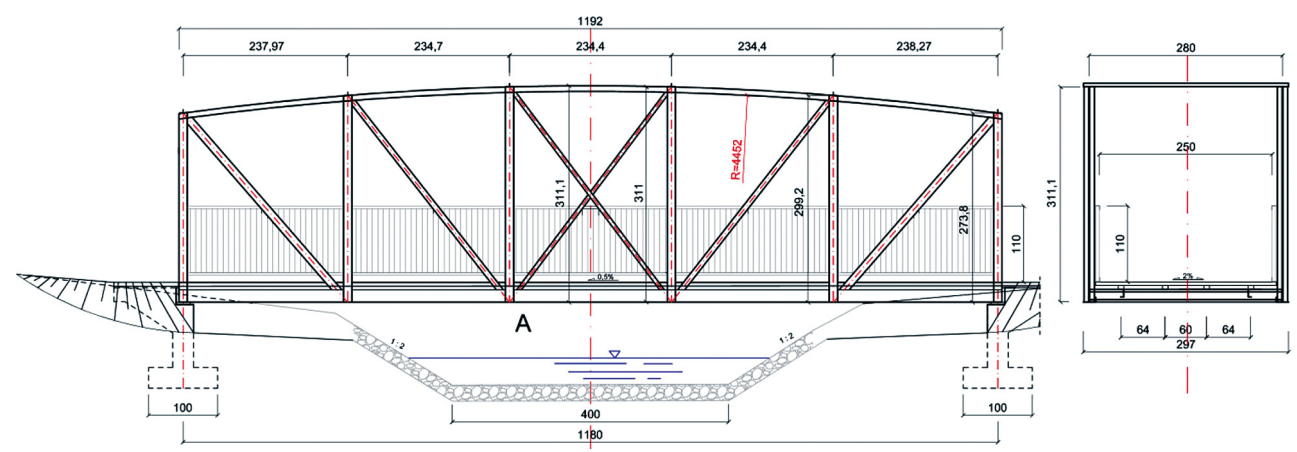

Rys. 11. Kładka kratownicowa, system Pratt' ${ }^{6}$ - wariant 2

Rys. 11, konstrukcja w całości jest metalowa. Pręty kratownicy mogą być wykonane z kształtowników (jak na rysunku) lub alternatywnie z rur o przekroju kwadratowym lub prostokątnym. Konsekwencją nieparzystej liczby pół kratownicy jest pełne skratowanie w polu środkowym, co wytwarza dominantę części centralnej kratownicy w widoku z boku. Górny pas jest w lekko wyniosłym łuku o promieniu $R=44,5 \mathrm{~m}$. Estetycznym atrybutem jest tu prostolinijność konstrukcji a łuk pasa górnego tylko ją uwypukla. W przekroju poprzecznym zarys jest prostokątny.
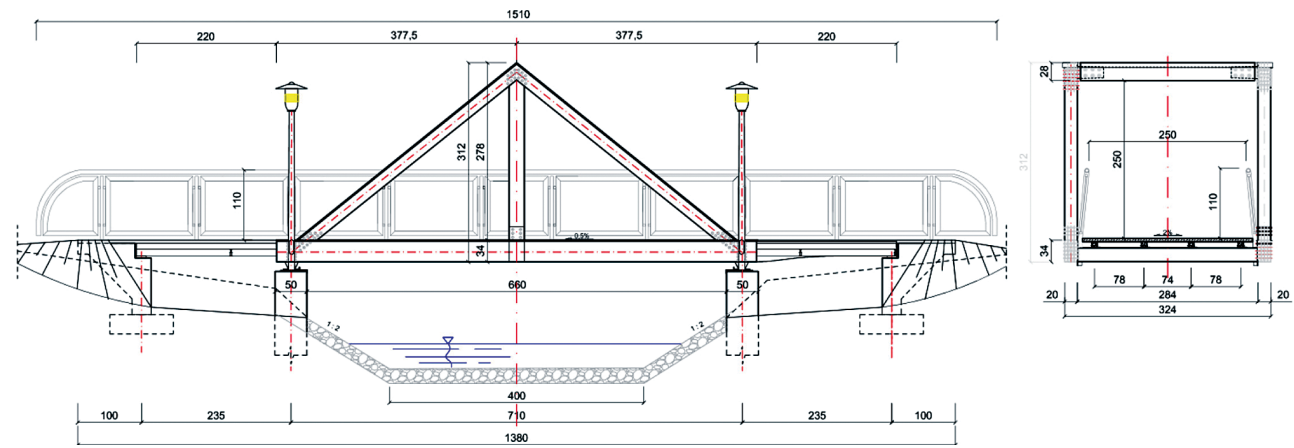

Rys. 12. Kładka kratownicowa, system Wadell'a ${ }^{7}$ - wariant 3

Na Rys. 12. przedstawiono stalową kratownicę Wadell'a, tworzącą centralne przęsło. Dodatkowo występują dwa krótkie przęsła, również stalowe, dojścia do kładki. Kratownica jest bardzo surowym kształtem, dlatego zastosowano dwa wertykale, jako lampy oświetleniowe oraz bardzo wyraźną ramę balustrady z wypełnieniami ze szkła hartowanego o łagodnych łukowych zakończeniach, które przez kontrast podkreślają ostrość trójkąta kratownicy. To jest odważna propozycja, w Polsce ten typ kratownicy mostowej nie jest stosowany. W przekroju poprzecznym, w czasie przechodzenia przez kładkę, widoczny jest kwadrat w miejscu środka mostu.

Reasumując ten rozdział, zaproponowano rozwiązania bazujące na przestrzennych strukturach, prostych $\mathrm{w}$ wykonaniu i silnym kształtowaniu obrazu mostu w planowanym otoczeniu.

\footnotetext{
6 Patent z 1844 r., złożony przez Thomasa i Caleba Pratt'ów jako modyfikacja schematu pony truss.

7 Patent z 1894 r., zgłoszony przez Johna A. L. Waddell’a, znany także jako kratownica A.
} 


\title{
4. Podsumowanie
}

Estetyka konstrukcji mostowych staje się coraz częściej ważnym elementem podczas projektowania [7]. W Polsce dominują małe mosty o średniej rozpiętości przęsła oscylującej wokół $20 \mathrm{~m}$. To te mosty kształtują krajobrazy architektoniczne wielu polskich miasteczek. Rodzi się pytanie czy należy budować mosty jako monumentalne rzeźby w terenie (Foldability of Space Frames) ? Oczywiście - tak. Jednak równie oczywiste jest to, że nie mogą to być wszystkie mosty. Większości małych obiektów może być typowa, przy czym nie kłóci się to $\mathrm{z}$ ich indywidualizacją przez stosowanie wyróżniających elementów lub barw. Kreowanie małych indywidualnych kładek dla pieszych jest tu szczególnie ważne. Właśnie tempo chodu ludzkiego sprawia, że postrzeganie obrazu jest zbliżone do oglądania filmu, jest dostatecznie dużo czasu na obejrzenie (interesującej estetycznie) konstrukcji mostu. Na pewną miarą uznania estetyki - synergii - jest chęć zrobienia zdjęcia, np. selfie z mostem.

Kierując się tymi założeniami odnaleziono w mostach z Parczewa wiele interesujących elementów estetycznych, które przez codzienne użytkowanie mostów zapadają w świadomość ich użytkowników. Podobnie zaproponowane warianty nowoprojektowanej kładki parkowej powstały z myślą o ich indywidualności w swoim środowisku.

\section{Literatura}

[1] Karas S. History of sustainable bridge solutions. Chapter 1, Structural Bridge Engineering, InTech, (2016) 1-24. DOI: 10.5772/63461.

[2] Horoch E., Koprukowniak A., Szczygieł R. Dzieje Parczewa 1401-2001. Urząd Miasta i Gminy Parczew, Parczew-Lublin 2001. http://dlibra.umcs.lublin.pl/dlibra/plain-content?id=387 [12.07.2017].

[3] Karaś S., Kossowski G. Nasunięcie przęsła Vierendeel'a w Lublinie. Przegląd Komunikacyjny 4 (2013) 16-24.

[4] Wasiutyński Z. O architekturze mostów. PWN, 1971.

[5] Łagoda G., Łagoda M. Aspekt estetyczny ksztaltowania obiektów mostowych. Drogi i Mosty 1 (2004) 55-86.

[6] Karaś S., Oskędra B., Skulski B. Nowy most lukowy w Szczebrzeszynie. MOSTY 6 (2015) 22-25.

[7] Dębiński M., Jukowski M., Karaś S., Kowal M., Leniak-Tomczyk A. (Ed.: Karaś S.). Aesthetics of road structures. Politechnika Lubelska, 2016. http://www.bc.pollub.pl/dlibra/docmetadata?i$\mathrm{d}=12857 \&$ from=publication. [12.07.2017].

\section{Synergy of structure and aesthetics of small bridges in Parczew}

\author{
Sławomir Karaś1 ${ }^{1}$, Karolina Jankowska ${ }^{2}$ \\ ${ }^{1}$ Department of Roads and Bridges, Faculty of Civil Engineering and Architecture, \\ Lublin University of Technology, e-mail: s.karas@pollub.pl \\ ${ }^{2}$ Budimex S.A., e-mail: karolina.jankowska@budimex.pl
}

\begin{abstract}
Due to their durability, bridges become landscape reference points in various aspects, especially from the social, architectural and aesthetic points of view. There are many
\end{abstract}


examples supporting the above, e.g. Tower Bridge, Puente del Alamillo, Pont Saint-Bénézet (d'Avignon), Karlův Bridge or Ponte Sant'Angelo. Nevertheless, the analyses conducted in this paper regard bridges much less renowned than the aforementioned ones, namely, the small bridges upon Konotopa and Piwonia rivers in the town of Parczew in Lubelszczyzna. The local community have deemed it necessary to change the ordinariness into an arrangement close to synergy which can be achieved through tending the bridges, enhancing their aesthetical value through displaying their mechanics, emphasising fundamental lines by means of strong or delicate colours, as well as through references to the environment of the bridges by harmonising them with it or, on the contrary, turning them into a local dominant. Plenty has been done so far as the progress in bridge design where the aesthetic aspect is into consideration is constant, which also results from a better understanding of sustainable development. The paper describes all the bridges in Parczew and its vicinity with regard to the residents' awareness of them. It discusses both road and railway bridges and contains their short service characteristics, history and subjective aesthetic assessment. The aforementioned concept was applied in the design of a small footbridge in three variants, where, apart from the questions of durability and functionality, the fundamental task was to use simple and visually attractive solutions - whatever it may mean.

Keywords: bridges, small cities, aesthetics, sustainable development. 
